\title{
Determination of carbonation degree of existing reinforced concrete structures and their restoration
}

\author{
Vladimir Rimshin ${ }^{1}$, Pavel Truntov ${ }^{1 *}$ \\ ${ }^{1}$ National Research Moscow State University of Civil Engineering, Yaroslavskoe shosse, 26, \\ Moscow, 129337, Russian Federation
}

\begin{abstract}
The research of carbonation of existing concrete structures presented in the article was executed in the process of conducting a technical survey of the building. According to the results of the study, places with varying degrees of carbonation were identified. A method for preparing the phenolphthalein solution used in the examination is described. A methodology for testing structures to determine the degree of carbonation is presented. The results of measuring the degree of carbonation of structures by the phenolphthalein method are presented. The data obtained show that the concentration of carbon dioxide has a significant effect on the corrosion process of reinforcing bars and the loss of the bearing capacity of structures during the operation of an existing building. A favorable range of $\mathrm{pH}$ values for concrete structures during operation is considered. The average actual depth of the neutralized concrete layer is determined. The method of restoration of building structures exposed to the carbonation reaction is described. The impact of carbonation on reinforced concrete structures during the operation of the building is assessed. The results of the restoration work are presented.
\end{abstract}

\section{Introduction}

Carbonization of reinforced concrete structures is one of the main reasons for the loss of the bearing capacity of building structures due to corrosion of reinforcement. Carbonation is the changes that occur in concrete on Portland cement when exposed to carbon dioxide $\mathrm{CO} 2$. The restoration of these structures should be carried out according to the results of a technical examination of the structures and the identification of the causes of increased carbonation. Obvious signs of carbonized concrete are the appearance of characteristic cracks and the destruction of the protective layer of concrete with corrosion of reinforcement.

Due to the destruction of concrete because of the corrosion of the reinforcement, it is necessary to initially restore the structure of concrete and then to possibly strengthen these structures in the future.

*Corresponding author: pavel_truntov@mail.ru 


\section{Materials and Methods}

The depth of concrete carbonization was determined using the phenolphthalein test method. To use $1 \%, 0.5 \%$ and $0.1 \%$ solutions of phenolphthalein in ethanol are allowed.

The phenolphthalein test method is based on the color change of the solution of the acid-base indicator on the surface of concrete and reinforced concrete, depending on the $\mathrm{pH}$ of its environment (fig. 1).

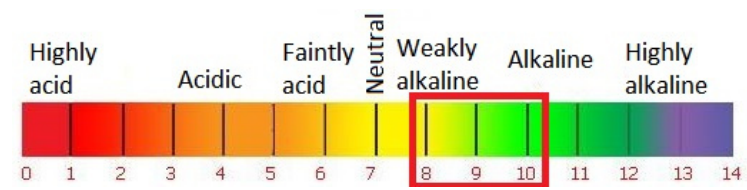

Fig. 1. PH range of color change of phenolphthalein solution

The $\mathrm{pH}$ value of non-carbonized concrete is in the range of 11.5-12.5. With this indicator, the medium is highly alkaline, which helps protect steel reinforcement from corrosion inside the concrete body. Carbonization leads to the saturation of concrete pores with carbon dioxide from the air, as a result of which the main component, "free" calcium hydroxide, is neutralized by the reaction:

$$
\mathrm{Ca}(\mathrm{OH})_{2}+\mathrm{CO}_{2} \rightarrow \mathrm{CaCO}_{3} \downarrow+\mathrm{H}_{2} \mathrm{O}
$$

The resulting calcium carbonate has a reduced alkaline environment and a $\mathrm{pH}$ value in the range from $8 \div 10$, which leads to the loss of the passivating effect of concrete in relation to steel reinforcement. The loss of the passivating effect of concrete to steel reinforcement leads to corrosion in a humid environment.

A solution of phenolphthalein is applied to a fresh chip (saw cut) of concrete produced on the test structure. In the range of $\mathrm{pH}$ values from $8 \div 10$, the color of the indicator solution changes from colorless to raspberry (pink-violet), which helps to identify foci of carbonization and allows you to determine their actual depth. The absence of color of the indicator solution on the concrete surface, without visible signs of corrosion damage during visual inspection, indicates the absence or small amount of carbonization.

\section{Results}

The object of the survey was built in 1974 .

Of the concrete slab which were formerly exposed to carbon dioxide $(\mathrm{CO} 2)$, as a result of which calcite $\mathrm{CaCO} 3$ was formed in the body of the structure (which indicates the process of carbonation in the body of the reinforced concrete structure) were taken to perform the study.

During the inspection the following was discovered:

1. Cracks in concrete formed as a result of reinforcement corrosion (fig, 2).

2. Destruction of the concrete protective layer.

3 . Violation of the adhesion of the working reinforcement to concrete due to corrosion of the reinforcement and destruction of concrete.

4. Baring and surface corrosion of reinforcement of the longitudinal edge of the concrete slab (fig. 3). 


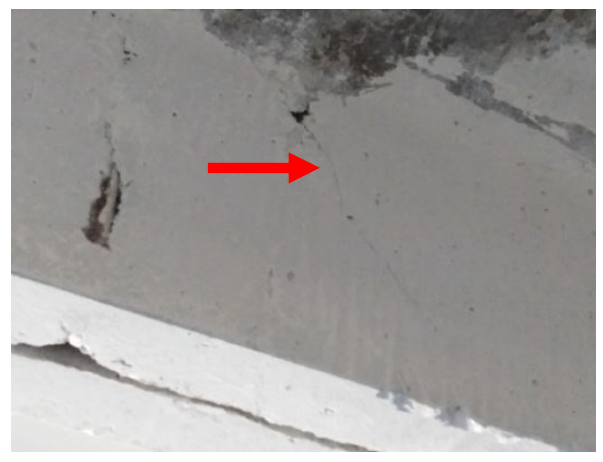

Fig. 2. Crack in the edge of the slab. Opening width up to $0.4 \mathrm{~mm}$.

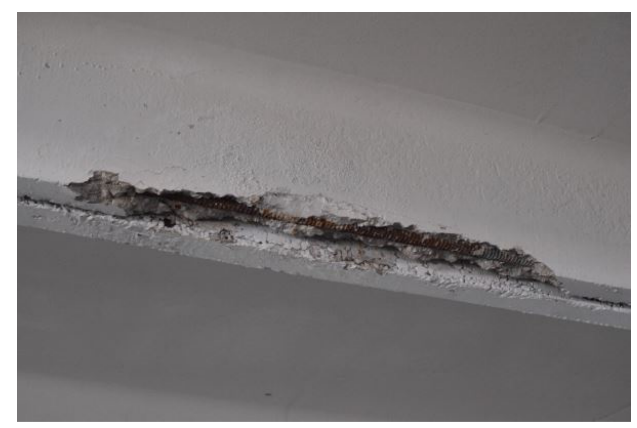

Fig. 3. Bare reinforcement and its surface corrosion with the destruction of the protective layer of concrete.

The detected defects and damages indicate a decrease in the hydrogen $\mathrm{pH}$ of concrete to values of $8 \div 10$, which leads to the loss of the passivating effect of concrete in relation to steel reinforcement.

To carry out the phenolphthalein test, we used a $1 \%$ solution of phenolphthalein in ethanol, prepared in accordance with the requirements of the Russian state standards GOST 4919.1-2016 and GOST 5962-2013. For this, $1 \mathrm{~g}$ of dry phenolphthalein is dissolved in 100 $\mathrm{cm} 3$ of ethyl alcohol by heating (or weak heating) in a water bath. In addition to phenolphthalein, $1 \%$ and $0.1 \%$ solution of orthocresolphthalein (dimethylphenolphthalein) is allowed for usage as an indicator.

The climate in the room is humid. The tests were performed on indoor structures with high humidity, typical for garage-type buildings.

The results of determining the depth of carbonation of concrete by phenolphthalein sample are listed in table 1.

Mean factual depth of neutralized layer (carbonation) is calculated using values from table 1 according to formula below:

$$
\mathrm{X}=\frac{\mathrm{\Sigma l}_{2} \mathrm{Xi}}{\mathrm{n}}
$$

where $n$ is the number of measurements.

Figures 4, 5 and 6 illustrate the results of the tests. 
Table 1. Values determining factual depth of carbonization due to phenolphthalein test results.

\begin{tabular}{|c|c|c|}
\hline $\begin{array}{c}\text { Autopsy } \\
\text { № }\end{array}$ & $\begin{array}{l}\text { Factual depth of } \\
\text { carbonization, mm }\end{array}$ & $\begin{array}{c}\text { Mean factual depth } \\
\text { of carbonization X, } \\
\text { sm }\end{array}$ \\
\hline 1 & $\begin{array}{c}\leq 45 \text { (deeper than } 5 \\
\mathrm{~mm})\end{array}$ & \multirow{12}{*}{2,56} \\
\hline 2 & None & \\
\hline 3 & None & \\
\hline 4 & $\leq 20$ & \\
\hline 5 & $\leq 20$ & \\
\hline 6 & None & \\
\hline 7 & $\begin{array}{c}\leq 50 \text { (deeper than } 10 \\
\mathrm{~mm})\end{array}$ & \\
\hline 8 & $\leq 15$ & \\
\hline 9 & $\leq 15$ & \\
\hline 10 & None & \\
\hline 11 & $\leq 20$ & \\
\hline 12 & $\leq 20$ & \\
\hline
\end{tabular}

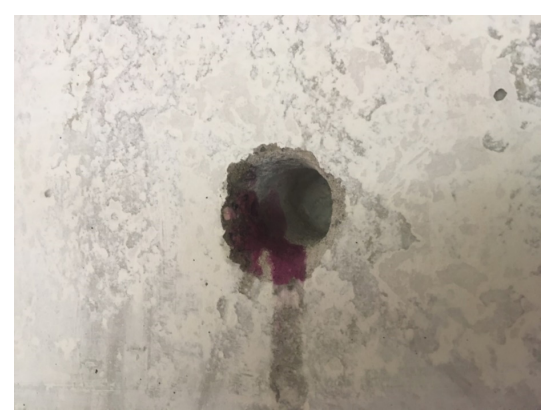

Fig. 4. Color change of phenolphthalein solution due to carbonation of concrete to a depth of $20 \mathrm{~mm}$, according to autopsy No. 4.

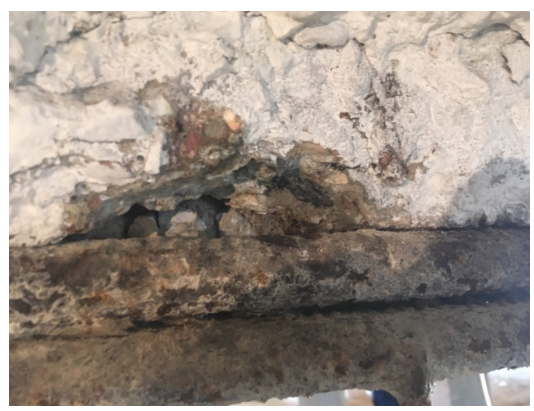

Fig. 5. The absence of visible signs of concrete carbonation according to the results of phenolphthalein samples in the areas behind the working reinforcement according to autopsy No. 2 . No concrete protective layer is present. 


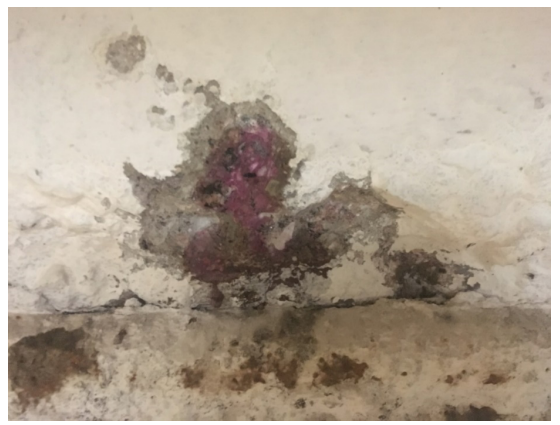

Fig. 6. The depth of carbonization according to the visual data of the phenolphthalein sample exceeds the value of the concrete protective layer by $10 \mathrm{~mm}$, according to the autopsy data No. 7 .

On autopsies №2, 3, 6, 10 there are no changes in the color of the phenolphthalein sample.

The resulting calcium carbonate has a reduced alkaline environment and a $\mathrm{pH}$ value in the range from $8 \div 10$, which leads to the loss of the passivating effect of concrete in relation to steel reinforcement.

The loss of the passivating effect of concrete to steel reinforcement leads to corrosion in a humid environment.

In the rest of the autopsies based on the results of the test, the hydrogen $\mathrm{pH}$ of noncarbonized concrete is in the range of $11.5=12.5$. The medium is highly alkaline, which helps protect steel reinforcement from corrosion inside the concrete body.

\section{Discussion}

According to the test results, repair and restoration of damaged concrete sections was performed. The carbonized concrete layer was removed by a mechanized method. When the depth of carbonation exceeds the thickness of the protective layer of concrete, damaged concrete is removed behind the reinforcement.

Wet cleaning of the repaired concrete surface from dust, paint residues and whitewash, as well as other contaminants, was carried out using neutral cleaning compounds.

After performing wet cleaning, drying of the cleaned surface was performed.

Cleaning the surface of the reinforcement from corrosion products was performed using manual metal brushes with further processing of the reinforcement with a corrosion converter. A tanit-based Docker Nittron neutral corrosion converter was used as they do not damage concrete or cement repair mixtures with an acidic environment, unlike acid corrosion converters.

Further, the restoration of the protective concrete layer was executed using non-shrink repair mixtures Master Emaco S488.

\section{Conclusions}

The presence of a humid environment and a $\mathrm{pH}$ value of $<10$ leads to the loss of the passivating effect of concrete in relation to steel reinforcement.

The process of restoration of carbonated building structures consists in the removal of carbonized concrete, up to concrete with a $\mathrm{pH}$ of $\approx 12$. The alkaline medium is characterized by the violet color of concrete during the phenolphthalein test. 
If the destruction of the protective layer of concrete and corrosion of the reinforcement is detected, the most probable cause is the carbonation of concrete with increased exposure to $\mathrm{CO}_{2}$ on the operated structure.

Considered restoration of carbonized structures increases the performance of restored structures.

\section{References}

1. N.I. Karpenko, V.A. Eryshev, V.I. Rimshin, IOP Conference Series: Materials Science and Engineering 463(3),032024 (2018).

2. V. Telichenko, V. Rimshin, E. Kuzina, IOP Conference Series: Materials Science and Engineering 463(3),032024 (2018).

3. A.L. Krishan, V.I. Rimshin, E.A. Troshkina, IOP Conference Series: Materials Science and Engineering 463(2),022062 (2018).

4. V. Telichenko, V. Rimshin, V. Eremeev, V. Kurbatov, MATEC Web of Conferences 196,02025 (2018).

5. A.A. Varlamov, V.I. Rimshin, S.Y. Tverskoi, IOP Conference Series: Earth and Environmental Science 177(1),012040 (2018).

6. V.I. Rimshin, B.V. Labudin, V.I. Melekhov, A. Orlov, V.L. Kurbatov, ARPN Journal of Engineering and Applied Sciences 13(11), 3851-3856 (2018).

7. E. Kuzina, V. Rimshin, Advances in Intelligent Systems and Computing 692, 410-416 (2018).

8. V.I. Rimshin, A.A. Varlamov, Izvestiya Vysshikh Uchebnykh Zavedenii, Seriya Teknologiya Tekstil'noi Promyshlennosti (3), 63-68 (2018)

9. V.I. Rimshin, A.A. Pudova, L.I. Shubin,. Izvestiya Vysshikh Uchebnykh Zavedenii, Seriya Teknologiya Tekstil'noi Promyshlennosti (3), 287-293 (2018).

10. E. Kuzina, A. Cherkas, V. Rimshin, IOP Conference Series: Materials Science and Engineering 365(3),032053 (2018).

11. A.A. Varlamov, V.I. Rimshin, S.Y. Tverskoi, IOP Conference Series: Materials Science and Engineering 463(2),022028 (2018).

12. A.A. Varlamov, V.I. Rimshin, S.Y. Tverskoi, Materials Science Forum 931, 340-345 (2018).

13. A.A. Varlamov, V.I. Rimshin, S.Y. Tverskoi, IFAC-PapersOnLine 51(30), 808-811 (2018).

14. A.L. Krishan, M.Yu. Narkevich, A.I. Sagadatov, V.I. Rimshin, IOP Conference Series: Materials Science and Engineering, 456(1),012049 (2018)

15. A. Cherkas, V. Rimshin, MATEC Web of Conferences 117,00027 (2017)

16. V.I. Telichenko, V.I. Rimshin, A.V. Karelskii, B.V. Labudin, V.L. Kurbatov, Journal of Industrial Pollution Control (2017)

17. A.L. Krishan, V.L. Rimshin, V.A. Rakhmanov, E.A. Troshkina, V.E. Kurbatov, . Izvestiya Vysshikh Uchebnykh Zavedenii, Seriya Teknologiya Tekstil'noi Promyshlennosti 370(4), 220-225 (2017)

18. I.L. Shubin, Y.V. Zaitsev, V.I. Rimshin, V.L. Kurbatov, P.S. Sultygova, Engineering Solid Mechanics. 5(2), 139-144 (2017) 
19. A.L. Krishan, V.I. Rimshin, V.I. Telichenko, V.A. Rakhmanov, M.Yu. Narkevich, Izvestiya Vysshikh Uchebnykh Zavedenii, Seriya Teknologiya Tekstil'noi Promyshlennosti 2017-January (2), 227-232 (2017).

20. S.A. Korotaev, V.I. Kalashnikov, V.I. Rimshin, I.V. Erofeeva, V.L. Kurbatov, Ecology, Environment and Conservation 22(3), 1159-1164 (2016).

21. Y.M. Bazhenov, V.T. Erofeev, V.I. Rimshin, S.V. Markov, V.L. Kurbatov, Engineering Solid Mechanics 4(4), 219-225 (2016)

22. A.L. Krishan, E.A. Troshkina, V.I. Rimshin, V.A. Rahmanov, V.L. Kurbatov, Research Journal of Pharmaceutical, Biological and Chemical Sciences 7(3), 2518-2529 (2016)

23. V.T. Erofeev, E.V. Zavalishin, V.I. Rimshin, V.L. Kurbatov, M.B. Stepanovich, Research Journal of Pharmaceutical, Biological and Chemical Sciences 7(3), 25062517 (2016).

24. V. Erofeev, V. Kalashnikov, S. Karpushin, I. Tretiakov, A. Matvievskiy, Solid State Phenomena 871, 28-32 (2016)

25. V.D. Antoshkin, V.I. Travush, V.T. Erofeev, V.I. Rimshin, V.L. Kurbatov, Modern Applied Science 9(3), 46-50 (2015)

26. A.A. Varlamov, V.I. Rimshin, S.Y. Tverskoi, IOP Conference Series: Materials Science and Engineering 463(2),022029 (2018)

27. A. Krishan, V. Rimshin, V. Erofeev, V. Kurbatov, S. Markov, Procedia Engineering 117(1), 211-217 (2015).

28. V.T. Erofeev, A.D. Bogatov, V.F. Smirnov, V.I. Rimshin, V.L. Kurbatov, Biosciences Biotechnology Research Asia 12(1), 661-669 (2015)

29. V.I. Rimshin, E.A. Larionov, V.T. Erofeyev, V.L. Kurbatov, Life Science Journal 11(11), 278-280 (2014)

30. V.M. Bondarenko, A.M. Kurzanov, V.I. Rimshin, Vestnik Rossijkoj Akademii Nauk 70(11), 1005-1009 (2000) 